\title{
Is what has been measured of any direct relevance to the success of the macrophyte in its particular environment?
}

\author{
Georg A. JANAUER
}

Institute of Ecology and Conservation Biology, Section of Hydrobotany, University of Vienna, Althanstrasse 14, A - 1091 Vienna, Austria

e-mail: georg.janauer@univie.ac.at

\begin{abstract}
In the aquatic environment biology and hydrology should assist each other in explaining the establishment, fluctuation, and limitation of the aquatic vegetation. However, the description of running and still waters by hydrology and habitat hydraulics, and the description of the aquatic vegetation, and its dynamics, rarely lead to results on a comparable scale. This is due to some intrinsic methodological features of both sciences, but also due to the fact that there is not much effort to find a common basis of scale. This is to no surprise because most of the time a hydrologist, and vice versa a biologist, tries to solve problems on his own, rarely calling for a partner from the other field. In the personal view of a biologist aspects are pointed out which may lead to a better interpretation of biological processes through habitat-related hydrological and/or hydraulic assessments. The terms macrophytes, environment and success are defined first. The function of macrophytes as a part of the aquatic ecosystem is explained, and related to important environmental factors. Examples are given for water flow as the most prominent abiotic factor. With respect to water flow and light the assessment of these parameters should be more detailed regarding space and time to be relevant to the scales in which aquatic plant life takes place. With regard to nutrient assessment spatial resolution is not as sensitive an issue as long as the water body, and not the interstitial, is concerned. However, any increase in detail will considerably raise the effort, and the cost, of data acquisition. Measuring plant "success" with physiological methods and biometrics can be too complicated for in situ work. Methods fitted to single species spatial development may cope with such problems and GIS is the tool to choose in such cases. Finally the urgent need to find common scales among hydrologists and biologists is addressed.
\end{abstract}

Key words: macrophytes, ecology, hydrology, habitat hydraulics, methodologies

\section{INTRODUCTION}

At first glance the topic looks trivial, but on a closer look it turns out to be more complex with each level of detail. This contribution cannot cover all the variability - nor the numerous transients - found in the aquatic and semi-aquatic environment, but it will try to point out some typical problems. Reviews on the topic are available from the past (Gessner 1955; Hutchinson 1975; Wetzel 1974) and some aspects of the structural aspect have been covered recently by Jeppesen et al. (1999). This contribution will concentrate on problems related to abiotic (physical and chemical) factors and hydrophytic plants, mainly the submersed forms, and on some difficulties in finding key parameters by which the situation of the aquatic plants can be described and which can be used to better predict the relationship between plants and aquatic habitat.

\section{DEFINITIONS}

\subsection{Macrophytes}

By definition the term "macrophytes" is used for aquatic plants, which can be determined to the species level by the eye (Westlake 1975; Wetzel 1975). This is a very practical, yet not really accurate definition - in a good number of cases the use of a magnifying glass or even a microscope is essential. With regard to taxonomy this term includes macro-algae (e.g. Cladophora, Chara), mosses and liverworts, ferns, and tracheophytes (Casper \& Krausch 1981; Frahm \& Frei 1992; Wetzel 1975).

The visual aspect of water bodies is often dominated by different growth forms of aquatic plants, which represent species with different morphological, i.e. spatial characteristics (Hutchinson 1975). Yet, the morphology of an aquatic plant may vary during its development, with respect to the seasonal period (e.g. leaf polymorphism), differences in light or nutrient availability, water depth, and wave action or current (Pieterse \& Murphy 1990). Without questioning scientifically elaborate classifications (den Hartog \& Segal 1964), more simple classifications are widely used for most applications (Hutchinson 1975; Pieterse \& Murphy 1990). Hydrophytes (Luther 1949, sensu Schouw 1822) are all plants adapted to life in the aquatic environment, either totally submersed, or with floating leafs and/or the inflorescence above the water. Rhizophytes (Luther 1949) are attached to the substrate by roots, rhizomes, rhiziods or other organs. Pleustophytes are divided into three categories (Luther 1949). Acro-pleustophytes have their assimilation organs floating on the water surface and the upper epidermis is adjusted to life in the air; plants floating in the water, where they may be attached to other, rooted plants are classified as meso-pleustophytes; plants floating right above, or being loosely an- 
chored to the sediment surface without special attachment organs are bentho-pleustophytes. Floating leaf plants are rhizophytes which have their leafs floating on the water surface. Helophytes are riparian plants and reeds which have only their roots and lower parts of the stem and leaves submersed (Hutchinson 1975). Amphiphytes are plants which follow the life strategy of aquatic plants, but turn into a fully terrestrial life form when the sediment falls dry (Wilmanns 1993).

The macrophytes are an essential part of many aquatic ecosystems. They are primary producers which produce biomass and oxygen. In addition to that macrophytes are structural elements in water bodies. Their surface, and the spaces between their roots, stems and leaves are inhabited by numerous forms of life, like bacteria and sessile algae, phyto- and zooplankton, invertebrates grazing and predating on the plant surface, different stages of fish life, amphibians and reptiles, water birds and mammals.

\subsection{Environment}

Macrophytes are found in running, and in still waters alike. With few exceptions this contribution deals with the abiotic, physical and chemical, aspects of the aquatic environment. Biotic factors can be just as important for the occurrence of species, but in many cases they are much less predictable and will not be considered here.

In natural environments the chemical composition, and the temperature, of a water body show only gradual changes regarding spatial, diurnal and seasonal fluctuation. All water plants are adapted to these regular changes, which are more important in stagnant waters then in running waters. There are environmental factors with steeper gradients and more frequent fluctuation: e.g. light and flow. The spatial distribution of incident radiation in the water body is much related to weather conditions, and to diurnal and seasonal changes. The light field is also modified by the bank vegetation, and by competition processes among individual macrophyte stands.

The spatial distribution of flow - comprising current velocities and turbulence in a three-dimensional set - is related to the discharge, which in turn depends on weather conditions and seasonal aspects, but also on the gradient and roughness of the river bed. Correlated factors are grain size distribution in the bed sediment, sediment transport, and turbidity. The whole picture gets more complicated when plants are present, as they develop spatial elements (leaves, stems, roots) in a plant stand, which is an elementary part of the aquatic vegetation in a specific stretch of a running, or still, water body.

\subsection{Success}

When brought down to the essentials success of a plant in its specific environment is the fulfilling of three demands: "Food - House - Propagation" (Davies 1998, personal communication). However, a description of this situation by exact numbers turns out to be more difficult. In a very general way the situation for a macrophyte is like that.

The environmental niche defined by the available nutrients is very wide for most aquatic plants. Only a few species may be limited to the risk of survival by the lack - or the surplus - of nutrients (e.g. $\mathrm{NH}_{4}$, Hutchinson 1975; Kohler 1978; Kohler et al. 1971). Absence of nutrients, like in some high alpine lakes prevents plant growth. Normally enough nutrients are available in water bodies to make macrophyte growth possible (Lohammar 1938). For plants light is essential, too. This makes deeply shaded areas uninhabitable for most species, but potential environments in rivers and still waters usually receive enough light for at least some species to survive there. Therefore, a "no food"situation, which totally limits aquatic plant growth rarely occurs in river stretches and still waters at medium and low elevation a.s.l.

Propagation is not essential for the survival of an individual, but it is a prime biological goal for plant life, too. Yet, many plants finish their life cycle as soon as they have produced propagules, which makes propagation a rather life limiting issue - unless vegetative propagation is practised.

The "house" of a macrophyte, the physical niche, is defined by the sediment (bed rock geology, grain size, chemical quality, organic content) on which the plant rests or into which it is anchored, and by the conditions defined by the ambient medium, the water. If either the sediment and/or the ambient flow conditions are unfavourable plants will not grow, physical conditions come first place in most habitats. Once a plant has been established nutrient concentration, intra- and inter-specific competition, and chances of propagation can vary over a wide range before its life gets restricted.

\section{FLOW: A DOMINANT ENVIRONMENTAL FACTOR}

Water flow is the most prominent environmental factor in running waters, but wave action and currents in still waters may not be neglected at all, as regards their potential to limit habitat availability (Lohammar 1938; Hutchinson 1975). Water flow in rivers is determined by hydrological parameters. In turn water flow defines grain size and sediment composition, channel type, and flood plain development. Water flow can be described by several parameters: mean flow in a channel, vertical flow distribution, discrete flow in habitats, uni-directional flow or turbulence. Its spatial and temporal variation is described as the flow regime and forms the background for mathematical models. Water flow interacts with the macrophyte vegetation, and species composition of the aquatic vegetation is an indicator for different flow conditions. 
Hary \& Janauer (1988) and Janauer (1997) described the dependence of macrophytes, and riparian vegetation, on types of flow regime in a back water system connected to the main channel of the Danube River using statistics and GIS overlays. Channel parts in which the water level and the direction of current change with a high frequency have limited aquatic vegetation as opposed to more stagnant reaches. Similar situations were reported for the Lobau area and several other back water systems (Janauer \& Kum 1996; Janauer \& Pall 1999a, b).

Another example for the strong relationship between macrophyte development and flow was found in free flowing reaches, and hydro-electric power plant impoundments on the Danube in Austria (Janauer 1999). Prior to the regulation fine substrates and mobile gravel dominated the meanders and anastomoses of the river and typical moss habitats did not exist. Today, the river is regulated and the banks are protected by rip-rap throughout its course in Austria. The hard, immobile substrate is perfect for mosses and makes them ubiquitous along the river. Their frequency is higher in free flowing reaches and constrained valleys. Close to power stations where current velocity is reduced tracheophytes are prevalent, although environmental parameters like turbidity, sediment type, bank type etc. are practically identical. Similar distributions of mosses and higher plants was detected in power plant impoundments in the German reach of the Danube (Pall \& Janauer 1995). Some species like Myriophyllum spicatum showed preferential growth in the upper reaches of the impoundments, whereas e.g. Potamogeton pectinatus and $P$. perfoliatus preferred locations closer to the power station. On a more general scale a "moss zone", typical for river reaches at higher altitudes is differentiated from a "tracheophyte zone" at lower elevation by plant sociological studies (Weber-Oldecop 1977; Wilmanns 1989). In contrast to that the references claimed above show that wherever large, immobile stones or boulders occur, mosses will prevail irrelevant of altitude, and - at least European - tracheophyte species will not grow on this substrate.

No macrophytes occurred in the main channel of the Danube between river-km 1826 and 1843 prior to the construction of the power plant in Gabcikovo (Slovakia). Today most of the water is led to the impoundment and except for flood periods not more than $500 \mathrm{~m}^{3} \mathrm{~s}^{-1}$ reach the "Old Danube", the former main river bed, where the mean annual discharge reached $2030 \mathrm{~m}^{3} \mathrm{~s}^{-1}$. Today, macrophytes have started to colonise suitable habitats in side branches and in macro-habitats in the old river bed, where water flow is slow or absent. Between 6 and 11 species were found in different survey stretches (Rath 1997).

The occurrence of aquatic vegetation in general and the occurrence of species is limited by the dynamics of the flow regime. This explains the existence of funda- mental ecotones, which occur wherever the realised niche is confined within the potential ecological niche by a dominant environmental factor (Janauer 1997; Dokulil et al. 1996). Other factors like competition among weed beds or the activity of herbivores (Mitchell \& Perrow 1998) can only modulate the threshold value to a small extent. The examples show that the aquatic vegetation forms a valuable bio-indicator system: plants integrate over time and over the fluctuations of environmental parameters like flow, which includes discharge, flow velocity, suspended solids transport, sediment reallocation in the bed, duration of flow regime types seasonal and diurnal, number and duration of spates, ice etc. However, for bio-indicator application more precise data on the physical conditions of aquatic plant habitats are still needed and the monitoring regime under the Water Framework Directive of the European Union will enforce relevant studies.

\section{DISCUSSION: TRADITIONAL MEASUREMENTS AND MODIFIED FUTURE APPROACHES}

\subsection{Light}

The radiation (full spectrum, photosynthetic active radiation, or selected wavelengths) reaching the surface of a river can easily be measured with different light meters (Kuchar 1995, Schoas 1994). The under-water light field is more complicated to assess since the attenuation of different wave lengths must be considered and light may come from more than one directions (Kirk 1983). Yet, measuring incident radiation above the water surface or within the water body is no great problem. What it needs is better spatial differentiation, e.g. small-sized grids, which mirror the dimensions of plant stands and their exact location in the water body. There is no doubt that such an investigation involves far more effort than a simple, single stand multiple measurement resulting in a single average value for a river stretch.

\subsection{Nutrients}

In the aquatic environment nutrients are not strictly confined to spatial units, as they are dissolved in the ambient medium, similar to carbon dioxide and oxygen which show no metabolism limiting gradients in the atmosphere. Marked concentration differences exist between the interstitial and the ambient water, and gradients may occur near the leafs of aquatic plants in still waters. Along a river stretch no great differences in nutrient concentrations will be found unless nutrients are brought into the river by ground water seepage or direct surface water discharge. This is one reason why many authors feel that "associations" sensu Braun-Blanquet (1964), often analogous to single beds of different species mutually occurring in the very same stretch of river, have a rather limited relevance for the differential indi- 
cation of trophic status. For such purposes Schneider's (2000) approach, based on individual species, nutrient content of the interstitial and the ambient water and weighted by frequency of occurrence, seems more promising. Yet, chemical analysis of nutrient parameters is no problem with regard to spatial and temporal detail, and bio-indication of trophic status by aquatic plants will stay a monitoring routine on a more general level.

\subsection{Flow}

Regardless of the fact that much is known about the hydraulics of water flow in rivers the detailed description of "micro"-hydraulics relevant to occurrence, prevalence and extinction of aquatic plants is still missing, at least seen from the biologists view (short review: Zalewski et al. 1997; Lillie \& Budd 1992).

Mean flow across a channel section is of little relevance to the flow conditions in a sediment pocket filled with silty material surrounded by gravel or larger stones, where a macrophyte may become rooted, and then may sustain higher velocities once it is well established. However, much later when the weed bed is fully grown the increasing hydraulic resistance may lead to the uprooting of the whole plant during a storm flood. To describe such phenomena too little information is given by discharge values, storm hydrographs, or even isovels in just a few cross sections of a single river stretch (Calow \& Petts 1993). To follow ecologically important changes in relevant scales a spatially much more detailed measuring strategy must be followed.

\subsection{Success}

A plant is considered successful if it achieves optimum growth rate and best results regarding propagation. The optimum growth rate can be assessed by measurements of net photosynthesis or biomass accumulation (Jorga \& Weise 1977), but neither has really been done under field conditions with destruction-free methods in situ. Moreover, when working with individual plants or plant parts statistics afford replicating, making in situ measurements even more complicated. Biometrics of plant parts can be practised, with much difficulties below the water surface, in situ. Related parameters like leaf area index (LAI), etc. are not easily assessed without destroying the plant.

Most methods on the level of whole plant stands are destructive, but some use only parts of the stand, e.g. stratified biomass sampling and stratified biometrics. The data describe the plant as a spatial element in a rather structureless environment. Normal harvesting per unit area certainly is the most effortless, but least differentiating approach..

Success may also be measured on the level of vegetation patches by describing species richness, or species frequency. Community structure is a term not used in quantitative, but rather in very general qualitative ways: its use for space oriented descriptions of the properties of vegetation patches is rather limited and has not found much acceptance in macrophyte studies.

Abundance is another term of rather general meaning, which is often used to describe the contribution of a species within a patch of vegetation. In continental Europe this term has a long tradition with the plant sociological approach (Braun-Blanquet 1964), but the scale used for the estimates of the cover of each species in the survey area does not follow a continuous function, which makes correct mathematical treatment of these data complicated and sometimes impossible. Less problematic is the estimate of relative cover (in \% of the total survey area, Londo 1984). More precise can be derived by (aerial) photography or (d)GPS or geodetic techniques, where applicable. All these approaches are rather restricted to terrestrial vegetation.

Since the vertical development of the aquatic vegetation varies according to living conditions cover estimates may not be sufficient to describe the success of the species. Therefore authors tried to include a threedimensional aspect into their field survey techniques from the beginning (Niemann 1980; Kohler et al. 1971, 1996). Methods following this approach estimate the "amount" of species (cover plus vertical development) in relation to river reaches, survey units, or test plots. These methods have been successfully used for monitoring seasonal and year-to-year fluctuations, and for comparisons of aquatic vegetation in different rivers (Janauer \& Wychera 2000; Würzbach et al. 1997).

Regarding propagation and plant success the number of propagules, their weight, and their germination potential can be studied. Neither of these parameters is one that would be a good indicator for field oriented on-thespot monitoring surveys. Another approach with sufficient accuracy for many problems is the mapping of plant stands on a single-species basis. This method meets the needs for precision, as well as those of scale used in detail-oriented hydrological and/or hydraulic investigations. In any case enhancing the spatial resolution is the prime goal.

\section{CONCLUSIONS}

As mentioned above there is no far reaching integration between biology and hydrology/habitat hydraulics at present. With regard to nutrient measurement, and the description of plant success there exist not many problems, but assessing the aspects of water movement in the plant habitat fails to be satisfactory, as the scales of investigation in biology and hydrology describe different niche sizes. The same is true for more traditional plant assessment methods, which often fail to give the needed information on the spatial distribution of species in the detail needed to make correct predictions, and correlations with habitat related hydrology. Much work on the integration of habitat hydrology and hydraulics with ecology of the aquatic vegetation is needed in the future, as spatial scales relevant to the objects under in- 
vestigation, i.e. the aquatic plant species in their natural environment, must be assessed. It will be necessary to accomplish also long-term studies to be able to distinguish short-time fluctuations from real changes in environmental conditions. When looking for well suited study areas one can start out where the "factor-integrating" aquatic vegetation shows pronounced differences in composition or "fundamental ecotones" over a reasonable time period. In the past, biologists have focused on measuring parameters which were not in alignment with the scales of hydrology and often even not with those of so called "habitat hydraulics". Considerably more detailed studies are necessary to reach down to the scale of habitats and river stretches in the field of the hydrological and hydraulic researcher, and to reach up regarding the scales of the biologist.

\section{ACKNOWLEDGMENTS}

A. Davies assisted in sculpting the outlines of this contribution with his pleasant, zestful and inspiring discussions. I would also like to thank all colleagues of CEN 270/Working Group 2 for their intensive exchange of ideas, especially J. Haury, a most brilliant botanist.

\section{REFERENCES}

Braun-Blanquet, J. 1964. Pflanzensoziologie. Springer Wien New York: 865pp.

Calow, P. \& G.E. Petts (Eds). 1993. The Rivers Handbook. Hydrological and ecological principles. Blackwell Scientific. London.

Casper, S.J. \& H.D. Krausch. 1981. Pteridophyta und Anthophyta 23/24. In: Ettl, H., Gerloff, J. \& H. Heynig (Eds), Die Süßwasserflora von Mitteleuropa. Gustav Fischer Verlag. Stuttgart: 942pp.

Den Hartog, C. \& S. Segal. 1964. A new classification of the water-plant communities. Acta Botanica Neerlandica, 13: 367-393.

Dokulil, M., G.A. Janauer \& G. Kum. 1996: Potential elementary ecotones structures: basic data for a synoptic analysis of backwater-system processes (Module 3, ÖDM - MaB). Arch. Hydrobiol., Suppl. 113: Large Rivers 10/1$4,507-512$

Frahm, J.-P. \& W. Frey. 1992. Moosflora. 3. Edition. Ulmer, Stuttgart: $525 \mathrm{pp}$.

Gessner, F. 1955. Hydrobotanik. Die physiologischen Grundlagen der Pflanzen-verbreitung im Wasser. VEB. Deutscher Verlag der Wissenschaften. Berlin: 549 pp.

Hary, N. \& G.A. Janauer. 1988. Interdisziplinäre Studie Donau. Planung + Umwelt. 6: 42-58.

Hutchinson, G.E. 1975. A treatise on limnology. III. Limnological Botany. John Wiley, New York: 660 pp.

Janauer, G.A. 1999. Macrophytes of the River Danube: a diversity study of the Austrian stretch. Arch. Hydrobiol., Suppl. Large Rivers, 11: 399-412.

Janauer, G.A. \& K. Pall. 1999b: Makrophytenvegetation des Gießganges Greifenstein. In: Aquatische und terrestrische Vegetation. Schriftenreihe der Forschung im Verbund, 53: 10-97.

Janauer, G.A. \& U. Wychera. 2000. Biodiversity, succession and the functioning role of macrophytes in the New Danube. Arch. Hydrobiol., Suppl. Large Rivers, 12: 61-74.

Janauer, G.A. 1997. Macrophytes, hydrology, and aquatic ecotones: a GIS-supported ecological survey. Aquatic Bot., 58: $379-391$.
Janauer, G.A. \& G. KUM. 1996. Macrophytes and floodplain water dynamics in the River Danube ecotone research region (Austria). Hydrobiologia, 340: 137-140.

Janauer, G.A. \& K. Pall. 1999a. Zur quantitativen Prognose von Veränderungen der Makrophytenvegetation nach Hochwasser-Dotation in den Auengewässern der Lobau (Wien): Kartierung von Einzelbeständen und GIS-Bearbeitung als methodischer Versuch. In: Umweltforschung im Dialog - aktuelle Beiträge aus dem mittleren Neckarraum. Hohenheimer Umwelttagung, 31: 215-226.

Jeppesen, E., Ma. Sondergaard, Mo. Sondergaard \& K. Christoffersen (Eds). 1998. The structuring role of submerged macrophytes in lakes. Ecological Studies, 131. Springer, New York: 423 pp.

Jorga, W. \& G. Weise, 1977. Biomasseentwicklung submerser Makrophyten in langsam fließender Gewässern in Beziehung zum Sauerstoffhaushalt. Int. Revue ges Hydrobiol., 62: 209-234.

Kirk, J.T.O. 1983. Light and photosynthesis in aquatic ecosystems. Cambridge University Press. Cambridge - New York: $401 \mathrm{pp}$.

Kohler, A. 1978. Methoden der Kartierung von Flora und Vegetation von Süßwasserbiotopen. Landschaft und Stadt, 10: $73-85$.

Kohler, A. Vollrath, H. \& E. Beisl. 1971. Zur Verbreitung, Vergesellschaftung und Ökologie der Gefäßmakrophyten im Fließgewässersystem Moosach (Münchner Ebene): Arch. Hydrobiol., 69: 333-365.

Kohler, A., V. Sipos \& S. Björk. 1996: Makrophyten-Vegetation und Standorte im humosen Bräkne-Fluß (Südschweden). Bot. Jahr. Syst., 118: 451-503.

Kuchar, F. 1995. Die vertikale Verteilung von Licht, Biomasse und Struktur in Makropyhtenbeständen von Ranunculus fluitans und Groenlandia densa. MSc Thesis, Vienna.

Lillie, R. \& J. Budd. 1992. Habitat architecture of Myriophyllum spicatum $\mathrm{L}$. as an index to habitat quality for fish and macroinvertebrates. J. Freshwat. Ecol., 7: 113-125.

Lohammar, G., 1938: Wasserchemie und Höhere Vegetation schwedischer Seen. Symbolae Botanicae Upsaliensis III:1. A.-B. Lundequistska Bokhandeln, Uppsala: 252pp.

Londo, G. 1984. The decimal scale for relevés of permanent quadrats. In: Kuap, R. (Ed.), Sampling methods and taxon analysis in vegetation science. Dr. W. Junk Publishers, The Hague: 45-49.

Luther, H. 1949. Vorschlag zu einer ökologischen Grundeinteilung der Hydrophyten. Acta Bot. Fenn., 44: 1-15.

Mitchell, St.F. \& M.R. Perrow. 1998. Interactions between grazing birds and macrophytes. In: Jeppesen, E., Sondergaard, M., Sondergaard, M. \& K. Christoffersen (Eds), The structuring role of submerged macrophytes in lakes. Ecological Studies, 131: 175-196.

Niemann, E. 1980. Zur Ansprache des "Verkrautungszustandes" in Fließgewässern. Acta Hydrochim. Hydrobiol., 8: 47-57.

Pall, K. \& G.A. Janauer. 1995. Die Makrophytenvegetation von Flußstauen am Beispiel der Donau zwischen Fluß-km 2552,0 und 2511,8 in der Bundesrepublik Deutschland. Arch. Hydrobiol., Suppl. Large Rivers, 9: 91-109.

Pieterse, A.H. \& K.J. Murphy. 1990. Aquatic Weeds. The ecology and management of nuisance aquatic vegetation. Oxford University Press: 593 pp.

Rath, B. 1997. Verbreitung von aquatischen Makrophytenbeständen im Flußbett des früheren Hauptarmes der Donau (Szigetköz, Stromkm 1826-1843). Proceedings 32. Conference of the International Association for Danube Research. Vienna: 227-232.

Schneider, S. 2000. Entwicklung eines Makrophytenindex zur Trophieindikation in Fließgewässern. Shaker Verlag, Aachen: 182 pp. 
Schoas, R. 1994. Vertikale Verteilung von Photosynthesepigmenten in zwei verschieden strukturierten Makrophytenbeständen. MSc Thesis, Vienna.

Weber-Oldecop, D.W. 1977. Fließgewässertypologie in Niedersachsen auf floristisch-soziologischer Grundlage. Götinger Florist. Rundbr., 10: 73-79.

Westlake, D.F. 1974. Macrophytes. In: Vollenweider, R.A. (Ed.), A manual on methods for measuring primary production in aquatic environments. IBP Handbook 12. Blackwell Scientific Publications, Oxford: 32-42.

Wetzel, R.G. 1975. Limnology. W.B.Saunders Comp., Philadelphia: $742 \mathrm{pp}$.
Wilmanns, 0. 1989. Ökologische Pflanzensoziologie. UTB 269. Quelle \& Meyer, Wiesbaden-Heidelberg. 372pp.

Würzbach, R., G.-H. Zeltner \& A. Kohler. 1997. Die Makrophyten-Vegetation des Fließgewässersystems der Moosach (Münchener Ebene) - Ihre Entwicklung von 1970 bis 1996. Ber. Inst. Landschafts- Pflanzenökologie Univ. Hohenheim, Beih. 4: 243-312.

Zalewski, M., G.A. Janauer \& G. Jolankai (Eds). 1997. Ecohydrology. A new paradigm for the sustainable use of aquatic resources. UNESCO, Paris: $58 \mathrm{pp}$. 